\title{
Students and young university staff development in the context of e-learning and the fourth industrial revolution
}

\author{
Le Doan Minh Duc ${ }^{1 *}$, Nguyen Hoang Tien ${ }^{1}$, Nguyen Thi Hoang Yen ${ }^{1}$ \\ ${ }^{1}$ Thu Dau Mot University, Vietnam \\ *Corresponding author: ledoanminhduc@gmail.com
}

\begin{abstract}
ARTICLE INFO
ABSTRACT

DOI: 10.46223/HCMCOUJS.

soci.en.9.1.270.2019

Received: April $9^{\text {th }}, 2019$

Revised: June $6^{\text {th }}, 2019$

Accepted: July $17^{\text {th }}, 2019$

This article aims at presenting the current state of students' capacity for learning and competencies of young staff members in Vietnamese universities. Then, we imply some orientations to improve students' capacity for learning and young lecturers' capacity for teaching in the $4^{\text {th }}$ industrial revolution such as:

Keywords:

e-learning, industrial Application of technology in teaching - education management revolution 4.0, students, studying capacity, young lecturers and international affair.
\end{abstract}

\section{Introduction}

In education, the most important factor deciding quality is not a material, but experience and competencies of academic lecturers and students 'capacity for self-studying, especially by multiple methods of distant learning. Tertiary education is treated normally as a bridge linking graduates with the labor market which is increasingly demanding and integrated worldwide. Due to that fact, the role of young academic staff becomes more and more vital and the enhancement of the quality of staff, especially young lecturers is a critical issue that should be put on the top of the agenda for university development. In addition, living in the age of the virtual world of Internet technology for education and progressing Industrial Revolution 4.0, students should be equipped with self-studying and distant learning capacity to acquire knowledge efficiently, adapting to the general requirements of the new time.

\section{The 4th industrial revolution - Challenges and opportunities}

There are really big differences between Vietnamese domestic students and international students (including Vietnamese students studying overseas) in terms of flexibility, adaptability, creativity, self-learning and distant learning capacity that are the ways and teaching methods at local and abroad universities. The problem starts from an early stage -high school. High school students study too much and have no time for entertainment, sport and creativity compared to their friends at the same age in developed countries. They may perform better, for example at university entrance exams where the knowledge of high school teaching programs is simply being verified. Vietnamese students may encounter problems when the 
exams take other forms to check the capacity of applying the learned knowledge such as logical thinking and reasoning with numbers in math, ideas and sentences in literature and foreign languages. At universities' stage of study where some elements of creativity and innovation, taking further initiatives are needed to acquire knowledge efficiently, especially by using diverse e-learning methods and technologies. In contrast, they (the foreign students) are simply used to such methods of learning, including also e-learning, and discovering things at an early age. Vietnamese students are full of stress since they struggle with taking additional courses and passing difficult exams which no creativity is required. This way, Vietnamese students have simply killed their innovative capacity desperately needed for Internet - based technology based on self-studying at university where the methods of teaching and learning, predominantly based on exploring and screening open learning resources online, self-discovering and independent thinking, are completely different from those at high school. If they are not going to change themselves quickly they will have real trouble with studying at foreign universities overseas and lag behind in competition with students of other nations (Nguyen, 2017a).

\section{The role of young academic lecturers to enhance students' e-learning capacities}

In Vietnamese universities, most lecturers are required to have a master's degree with classified as outstanding or excellent. After that, they have to strive for the highest degree, namely $\mathrm{Ph} . \mathrm{D}$. degree. However, it is always impossible for everyone for various familiar reasons. That's why in many key universities countrywide, the proportion of lectures with master' degrees is predominant but in local universities even none of the academic lecturers have Ph.D. degrees. The next problem of Vietnamese universities is the process of promotion from Ph.D. to Associate Professor/Professor. In order to do that candidates must carry out many researches and international articles. As we know, Vietnam is known for a small number of $\mathrm{Ph}$.D. professors, compared with regional and global universities. Thus it is very hard to be promoted to such academic titles. Those who have an international Ph.D. degree will work in a pleasant working environment, contact with high-ranking professors that help them push forward their international publication and recognition (Nguyen, 2018).

In developed countries, academic lectures should meet the high requirements of academic degrees and titles, so they are very different from the business environment outside where pressure and priority are put on business experience and working performance. First class professors who are in a position of authority are renown in society and in the scientific world. Their most important role is to help students and the next generations develop their full potential. Young lecturers will sign a 5- to-7-year- labor contract with their universities if they meet the minimum requirements of a Ph.D. degree and post-doc studies. During the period of time, their main focus of attention is scientific research and publication in order to fulfill the requirements for becoming a professor. Otherwise, they should leave the university environment to find other suitable jobs. If a university cannot sign long term labor contracts with at least ten professors it is not allowed to open a concrete major and enroll students because of a lack of Ph.D. professors as key faculty staff members (Nguyen, 2018).

The above analyses show us the difference in terms of quality and professionalism between domestic and international academic teaching staff. This difference stems predominantly from an intellectual level, socio-economic development, science-technology background, environment, culture and traditions of each nation. To bridge the gap of distance 
in terms of teaching quality and publication capacity, Vietnamese teaching and researching staff can overcome their weaknesses and shortcomings using e-learning technology in teaching and doing research at local or international levels. E-learning, e-researching technologies are to level up local and global disparity and bring development opportunities for all, especially in the tertiary education sector.

We aim at developing and improving the potential and competencies of Vietnamese young lectures in the age of virtual society and digital economy we should analyze and investigate the needs more as well as the urgency of total education reform in the context of the Internet-based education technology, open learning resources accessible to the Internet and the development of the $4^{\text {th }}$ Industrial Revolution.

\section{The 4th industrial revolution - Challenges and opportunities}

The term "Industrial Revolution 4.0" or "the $4^{\text {th }}$ Industrial Revolution" (the $4^{\text {th }}$ IR or IR 4.0) has been mentioned for the first time in 2011 at the Hannover fair presenting industrial program 4.0 to boost Germany's traditional branch of automation and mechanics. A group of experts on industry 4.0 has presented a series of recommendations on industrial modernization and implementation for German government. They are considered as fathers and driving forces behind the so called Industrie 4.0 (Ho, 2017).

"Industrie 4.0" connect embedded system and smart production bases to create a digital convergence of industries, businesses, their functions and internal processes (Ho, 2017).

The first three world industrial revolutions have been presented in table 1. Currently, the $4^{\text {th }}$ industrial revolution stems from the 3 rd industrial revolution, connecting all technologies together, deleting the boundary between the physical world, virtual world and biological living world. According to Schwab (2016), the speed of change of the $4^{\text {th }}$ industrial revolution is unprecedented. Comparing to previous revolutions, the $4^{\text {th }}$ revolution develops with not linear but exponential speed. On top of that, due to interdisciplinary character and with ICT as a background, it currently destroys all structures of industrial branches in all countries. It premonish the transformation, both extensively and intensively, of the production, business and management systems worldwide.

\section{Table 1}

World industrial revolutions

\begin{tabular}{|c|c|l|}
\hline IR & Time period & \multicolumn{1}{c|}{ Technological content } \\
\hline 1.0 & $1820-1870$ & $\begin{array}{l}\text { Transport and communication. } \\
\text { Steam engine. }\end{array}$ \\
\hline 2.0 & $1870-1913$ & $\begin{array}{l}\text { Traditional industries (agriculture, heavy industries, mechanics, } \\
\text { metallurgy, chemistry) in developed countries. } \\
\text { Electrical engine. }\end{array}$ \\
\hline
\end{tabular}




\begin{tabular}{|c|l|l|}
\hline IR & Time period & \multicolumn{1}{|c|}{ Technological content } \\
\hline 3.0 & $1913-1950$ & $\begin{array}{l}\text { New technologies such as: Energy, space and aviation } \\
\text { technology, biotechnology, military technology, information } \\
\text { and communication technology. } \\
\text { Informatization and automatization. }\end{array}$ \\
\hline \multirow{5}{*}{4.0} & $\begin{array}{l}\text { Technology integration based on ICT platforms. } \\
\text {-Social Network } \\
\text { 1950-present } \\
\text {-Artificial Intelligence, Machine Learning } \\
\text {-Internet of Things } \\
\text {-Big Data } \\
\text {-3D Printer } \\
\text {-Virtual Reality } \\
\text {-Cloud and Cognitive Computing } \\
\text {-Driverless cars, Drones } \\
\text {-Smart robot, factory and city } \\
\text {-E-Learning, telemedicine }\end{array}$ \\
\hline
\end{tabular}

Source: Khuong Nha và Duy Tin (2017); Ho (2017)

Currently, IR 4.0 is taking place in America, Europe and parts of Asia (Japan, South Korea) first. Besides new opportunities, IR 4.0 also puts forward many challenges for humankind. Table 2 presents those opportunities and challenges related to IR 4.0 for organizations, economy and society.

\section{Table 2}

Opportunities and challenges due to the $4^{\text {th }}$ industrial revolution

\begin{tabular}{|c|l|l|}
\hline & \multicolumn{1}{|c|}{ Opportunities } & \multicolumn{1}{|c|}{ Challenges } \\
\hline 1 & $\begin{array}{l}\text { Many new professions, new jobs and new } \\
\text { entrepreneurship chances }\end{array}$ & $\begin{array}{l}\text { Instability, inequality, imbalance } \\
\text { in the labor market. }\end{array}$ \\
\hline 2 & $\begin{array}{l}\text { Enhanced working and production's productivity. } \\
\text { Economic growth based on new business models. }\end{array}$ & $\begin{array}{l}\text { How to educate human resources } \\
\text { that converge proper skills and } \\
\text { competencies. }\end{array}$ \\
\hline 3 & $\begin{array}{l}\text { High personalization, social connections are done } \\
\text { on many new modes. }\end{array}$ & $\begin{array}{l}\text { Traditional ways of production, } \\
\text { distribution and consumption } \\
\text { have been totally changed }\end{array}$ \\
\hline
\end{tabular}




\begin{tabular}{|l|l|l|}
\hline & \multicolumn{1}{|c|}{ Opportunities } & \multicolumn{1}{|c|}{ Challenges } \\
\hline 4 & $\begin{array}{l}\text { Proactive and innovative (creative) mind is an } \\
\text { advantage of individual and business }\end{array}$ & $\begin{array}{l}\text { Developing countries will lose } \\
\text { their advantages based on cheap } \\
\text { labor cost. }\end{array}$ \\
\hline
\end{tabular}

Source: Nguyen (2017b)

Facing the opportunities and challenges mentioned above what national governments, businesses and entrepreneurs can do to succeed and gain sustainable competitive advantages in the context of the upcoming IR 4.0 and knowledge-based economy where education is the most important sector and contributor to GDP growth and social development? Next, what is the role of universities, its young staff and students will be for businesses and institutions in the economy. Of course, basically, all universities are facing similar opportunities and challenges. Most of those opportunities and challenges are related to advanced e-learning technology development and the surrounding environment that supports knowledge acquisition.

\section{Competencies of young lecturers in Vietnam universities}

Comparing to foreign countries, in general, Vietnamese academic staff looks very young as if men reaching 60, women reaching 50, both of them, with some exceptions, should retire. Meanwhile, professors of foreign universities will work as long as they can, without limit of age and this is specific to tertiary education. Especially, life expectancy in developed countries is exceptionally long. In practice, almost all Vietnamese academic staff is young. So we should determine our own research for a young faculty member under 40 despite some other professions and the threshold of age, even a reason for earlier retirement (i.e., in sport or professions that cause serious damage to human health).

Senior academic staff in Vietnamese universities are conservative, and bigger in other epochs and consequently, they are reluctant to changes in terms of radical educational reforms and not suitable to follow the achievements and as well as innovations brought about by elearning technology and the IR 4.0. So, all the hopes are put on younger tech-generations easily and prone to accept new forms of knowledge acquisition, to welcome and foster new ideas and to promote innovative changes initiated by Internet-based technology and IR 4.0 and integrative trends spilled all around the world. They are tasked to lead the younger generation of students to follow their step, to adapt quickly and conveniently to the fast changing world of science and technology where the capacity of distant learning, creating and discovering new frontier of knowledge using open source e-learning materials is both passionate and important not only for them but also for everyone regardless age, belief, profession, social position, desiring to better function in an age of e-society, e-economy and IR 4.0 and take full advantage of the upcoming changes and opportunities.

For younger generations of teaching staff to carry out this serious mission and to fulfill the expectations of the society, they should be trained and developed accordingly in order to gain suitable competencies include knowledge, skills and attitudes that need constant changes and updates following new trends in the world. This could be done effectively only by distant (individual and collective) learning modes. Given the current quite unfavorable conditions of Vietnamese education system mentioned above, the young generation of teaching staff encounter many barriers that need to be overcome to fit in a totally-reformed education system 
directed towards opportunities and challenged offered by e-learning, Internet-based technologies and IR 4.0.

\section{Recommendations for development of young lecturers enhance students' e- learning capacities}

How to make tertiary education and its actors (students and young staff of academic lectures) the main driving force to propel socio-economic development in such, less favorable and less innovative current conditions in Vietnam? Hereafter are several solutions proposed by the author to enhance young academic staff's and competencies to promote students' distant learning (for the self-studying and knowledge acquiring purpose) capacity for the universities to fulfill their expectation, execute their mission and carry out their function by exploring the existing opportunities and dealing with challenges of irreversible trends of all-round integration and enabling e-technology offered by IR 4.0.

a) Policy and strategy for tertiary education development - as well-known, Vietnamese government and party prioritizes investment in education and are striving to do everything, by all means, to improve education quality following step of South Korea. Investment in education, especially in the application of wide popular e-learning technology is a top priority and precondition to boost knowledge based economy embraced by including IR 4.0. With limited resources, more investment should be there to boost young talent, including discovering and promoting super-youth students to become role model for others striving for the same success. It is best to use selective distant learning technology and strategy in terms of investment in some key universities, in some key majors, and in some age group of lectures (preferably young generations).

b) International cooperation and staff exchange - With limited resources and potentials, Vietnamese universities cannot be developed on their own feet. Foreign cooperation and support are needed, not only in the financial aspect. Student and staff exchange is needed to make friends with students and colleagues from other parts of the world in order to be acquainted with and to get on with international standards of teaching, studying and academic life at globally renowned universities. All of that can be perfectly done by using Internet-based technology enabling distant learning, researching and exchange of knowledge and experiences with diverse counterparts across the globe.

c) Learning foreign experiences of professional education management - Education is one of the important industries in an economy, so it should be managed professionally to be effective as well. Experiences of this field should be transferred from overseas, where education has a much longer history of development. This concerns both students and young lecturing staff. Tertiary education development and management could also be effectively done and significantly improved by omnipresent e-enabling technology.

d) Integrating the newest technology with e-educational processes - In the current context of the IR 4.0 without the help of technology, nothing can be done. Widest scope of integrated technologies should be applied to enhance and to ease educational processes, education management processes, teaching and learning activities of young lecturers and students, increasing their efficiency, mostly by bringing most of those activities into the virtual world online. 
e) Enhancing and internationalizing cultural environment within the university - It is worth creating a strong and open new technology cultural environment to support processes of distant researching, teaching, learning, management and their general effectiveness at different levels of university. All cultural values and identities of the university are constantly developing over time and should be gradually transformed due to the trend of integration, internationalization, and virtualization under the impact of quickly evolving technology determined by IR 4.0. Culture change presents a lot of opportunities for students to create an open, active and creative learning environment that benefits the process of knowledge, skills and attitude acquisition.

Balanced and sustainable development - In a world of lightning changes, innovation, transformation, reformation in terms of both technology (IR 4.0) and sociology (however less intensive changes in different fields and different levels and corners of the society) a balanced and sustainable approach to general organizational development is recommended and needed to calm down the radical technology changes in order to make up sociological and individual changes, at least at the level of distant learning students and distant teaching and doing research young staff within the framework of latest and newest technological developments associated with IR 4.0.

\section{References}

Ho, B. T. (2017). Hiểu về cách mạng công nghiệp lần thứ 4 [Understand the 4th industrial revolution save translation] . Retrieved October 10, 2018, from https://vnexpress.net/tintuc/khoa-hoc/hieu-ve-cach-mang-cong-nghiep-lan-thu-4-3574624.html

Khuong Nha, \& Duy Tin (2017). Cách mạng Công nghiệp 4.0 là gì? [What is Industrial Revolution 4.0?] . Retrieved October 15, 2018, from https://news.zing.vn/cach-mangcong-nghiep-40-la-gi-post750267.html.

Nguyen, T. H. (2017a). Challenges and opportunities for enterprises in the world of the 4th industrial revolution. Paper presented at the National conference on "Accounting, auditing and Vietnam economy in context of the 4th industrial revolution", Quy Nhon University, Quy Nhon, Vietnam.

Nguyen, T. H. (2017b). Entrepreneurship in international business. Lecturing and e-learning material of "International Business" course for internal use 2014-2017. Thu Dau Mot Univerisity, Vietnam.

Nguyen, T. H. (2018). Young university staff development in context of industrial revolution 4.0. Proceeding of University Scientific Conference "Young university staff toward education innovation and Industrial Revolution 4.0”.

Schwab, K. (2016). The fourth industrial revolution . Retrieved October 20, 2018, from World Economic Forum website: https:/www.weforum.org/about/the-fourth-industrialrevolution-by-klaus-schwab/ 